\title{
Stress Corrosion Cracking of Friction Stir Welding (FSW) of AW 5083 and AW 5059 Aluminium Alloys
}

\author{
MIROSŁAW CZECHOWSKI \\ Faculty of Marine Engineering \\ Gdynia Maritime University \\ Morska St., 81, 81-225 Gdynia, \\ POLAND
}

\begin{abstract}
Friction stir welding (FSW) joints of AW 5083 and AW 5059 alloys were used for the study. Mechanical properties, resistance to stress corrosion cracking (SCC) were investigated and metallographic tests were performed using an optical and scanning microscope (SEM). The parameters of friction welding are also given. Stress corrosion was investigated by the method of slow strain rate testing (SSRT) in air and $4.5 \% \mathrm{NaCl}$ aqueous solution. During SCC tests elongation, strength, fracture energy and time to break were measured. Very good strength of the tested alloys was found with good resistance to stress corrosion cracking. The aim of the study was to determine the possibility of using the AW 5059 and AW 5083 friction welded (FSW) alloys in marine structures, using stress corrosion resistance as a criterion.
\end{abstract}

Key-Words: - Al-Mg alloy, stress corrosion cracking, welded joints

Received: March 25, 2020. Revised: September 27, 2020. Accepted: October 10, 2020. Published: October 27, 2020.

\section{Introduction}

Depending on the external conditions, aluminum alloys and their welded joints may undergo various types of degradation under operating conditions. One of the important forms of operational damage leading to material degradation (cracks) is stress corrosion cracking. Susceptibility of aluminum - magnesium alloys to SCC depends on such factors as: the chemical composition of the alloys and the technology of their production [5]. The paper [5] presents the effect of $\mathrm{Mg}$ percentage in aluminum alloys on susceptibility to intergranular corrosion. At the content of $\mathrm{Mg}$ in $\mathrm{Al}$ alloys above $1.4 \%$ (solubility of magnesium in solid aluminum at room temperature), the $\mathrm{Al}_{3} \mathrm{Mg}_{2}$ (or $\mathrm{Al}_{8} \mathrm{Mg}_{5}$ ) intermetallic phase is formed, which is an anode in relation to the solid solution. Alloys with a $\mathrm{Mg}$ content of up to $3 \%$ are considered resistant to intercrystalline corrosion. Aluminum-magnesium alloys with a magnesium content above $3 \%$ may - after incorrect processing technology - contain a significant amount of $\mathrm{Al}_{3} \mathrm{Mg}_{2}$ phase, which contributes to the formation of intercrystalline or stress corrosion. It depends on the heat treatment of the alloy - the time and temperature of the annealing. The alloy 5083 (AlMg4.5Mn) is considered to be corrosion-resistant. Corrosion resistance decreases in welded joints of aluminum alloys. The corrosion resistance of welded joints depends on the welding technology and method as well as the type of additional material used. The literature contains the results of tests of susceptibility to stress corrosion and fatigue corrosion for aluminummagnesium alloys welded with the known TIG and MIG methods. There is no detailed information on the degradation of welded joints of aluminum alloys, the recently used Friction Stir Welding (FSW) method $[1,2,3,4,9]$. The literature on the subject contains a small number of studies on the susceptibility to corrosion in seawater of joints of aluminum alloys from the $2 \mathrm{xxx}$ group or the $7 \mathrm{xxx}$ group welded with the Friction Stir Welding method $[6,7,8]$. There are no results in the literature comparing the susceptibility to SCC of aluminum-magnesium joints welded using the FSW method with joints made by other welding methods, e.g. MIG method. Determining the SCC resistance of the AW 5083 and AW 5059 alloy welded with the FSW method and, for comparison, with the MIG method, will allow to find the optimal welding method. This method should ensure high strength of welded joints with good resistance to stress corrosion cracking. 


\section{Concept of experimental research}

\subsection{Material for research}

The alloys used in shipbuilding - $5083 \mathrm{H} 321$ and AW 5059 [AlMg5MnZn] H321 were tested. Table 1 shows the chemical composition of the alloys.

Welded joints of AW 5083 and AW 5059 aluminum alloys were made using the FSW method and the MIG method. Sheets $\mathrm{g}=12 \mathrm{~mm}$ thick were welded on both sides. The welding parameters are presented in Table 2. The parameters and technology of FSW welding are described in the publication [2]

Table 1. Chemical composition of the 5083 and 5059 aluminium alloys (wt. \%)

\begin{tabular}{ccc}
\hline & AW-5083 & AW-5059 \\
\hline $\mathrm{Si}$ & 0.195 & 0.037 \\
$\mathrm{Fe}$ & 0.18 & 0.092 \\
$\mathrm{Mn}$ & 0.66 & 0.767 \\
$\mathrm{Cu}$ & 0.09 & 0.011 \\
$\mathrm{Mg}$ & 4.74 & 5.411 \\
$\mathrm{Zn}$ & 0.042 & 0.571 \\
$\mathrm{Cr}$ & 0.11 & 0.003 \\
$\mathrm{Ti}$ & 0.02 & 0.024 \\
$\mathrm{Ni}$ & 0.005 & 0.004 \\
$\mathrm{Zr}$ & 0.003 & 0.114 \\
$\mathrm{Al}$ & rest & rest
\end{tabular}

During welding, the surface of the tool stop ring was inclined at an angle $\alpha=2^{\circ}$ (Fig. 1) to the surface of the sheet to be welded. Metallographic tests of welded joints using the FSW method showed the correct construction of the joint without cracks in the plastically deformed material (Figs. 2 and 3).

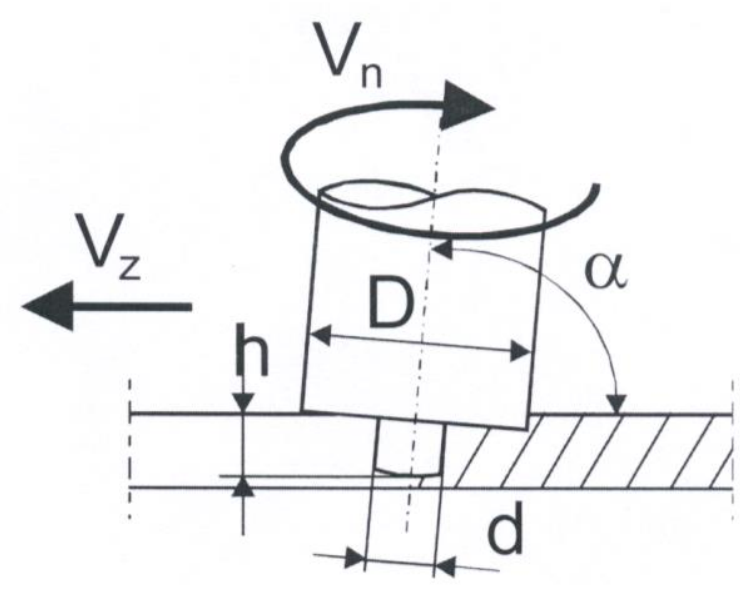

Fig. 1. Scheme of friction stir welding (FSW) [3].

\subsection{Structure of FSW welded joints}

During FSW welding, microstructures are formed that cannot be observed with other welding methods. The microstructures of the FSW welded joint are revealed when examining the etched specimens under a light microscope. The following areas can be distinguished in the weld: a layer of mixed alloys in the central part called the weld's nugget, the thermo-mechanical affected zone (TMAZ), the heat-affected zone (HAZ) and the intact alloy (Fig. 2).

Table 2. Parameters of sheet welding using the FSW method [2]

\begin{tabular}{ccccc}
\hline Alloy & $\begin{array}{c}\text { Passage } \\
\text { number }\end{array}$ & $\mathrm{h}$ & $\begin{array}{c}\text { Mandrel's } \\
\text { rotary } \\
\text { speed } \\
\text { Vn } \\
{[\mathrm{rev} . / \mathrm{min}]}\end{array}$ & $\begin{array}{c}\text { Welding } \\
\text { speed } \\
\text { Vz } \\
{[\mathrm{mm}]}\end{array}$ \\
\hline 5058 & I & 6 & 900 & 140 \\
& II & 3 & 900 & 180 \\
\hline 5059 & I & 6 & 560 & 180 \\
& II & 3 & 560 & 180 \\
\hline
\end{tabular}

$\mathrm{D}=20 \mathrm{~mm} ; \mathrm{d}=6 \mathrm{~mm}$

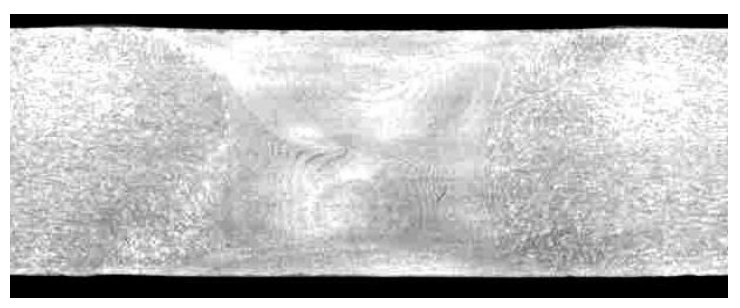

Fig. 2. The section of the joint welded by FSW method in two passages. 5083 alloy. Etching with Keller's reagent.

Figure 3 show characteristic microstructures of the weld's nugget and thermo-mechanically affected zone. The transition from the deformed alloy to the native alloy may take place from the attacking side or from the material's flow (Fig. 4 and 5). Participation of individual areas in the formation of weld depends on welding technology and the type of material to be welded. The weld's nugget arises as result of the material squeezing around mandrel. The material squeezed around the mandrel is forced into circular movement connected to appropriately profiled 
mandrel's protrusions. A layer of strongly strained material, which is affected mainly by the resistance rim, appears above the nugget.

Rotating the tool in the contact point between two sheets causes the material's rotational movement in the same direction as the tool does. It causes good mixing of the contact area. During that stirring process oxides in the weld face shatter in the material and the particles in the native material are broken up.

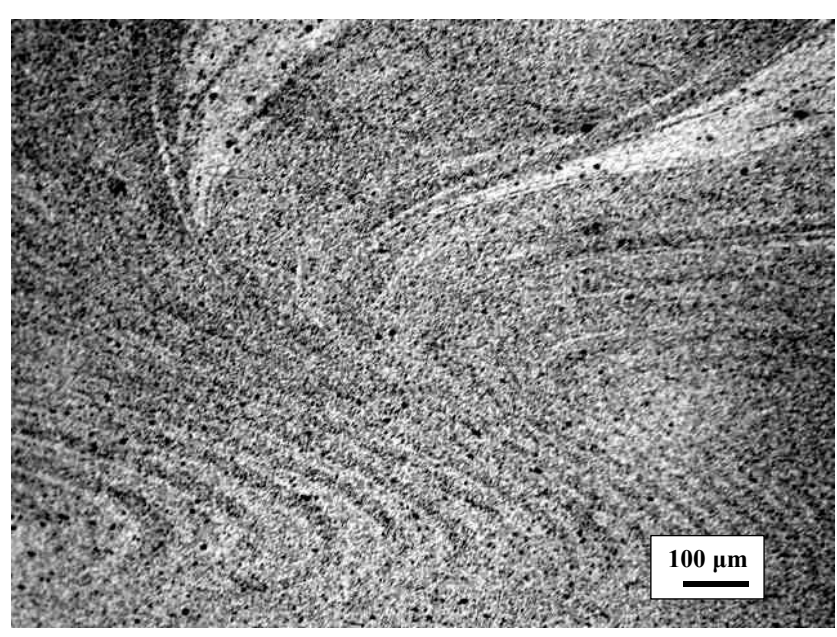

Fig. 3. Microstructure of 5083 alloy (the weld's nugget).

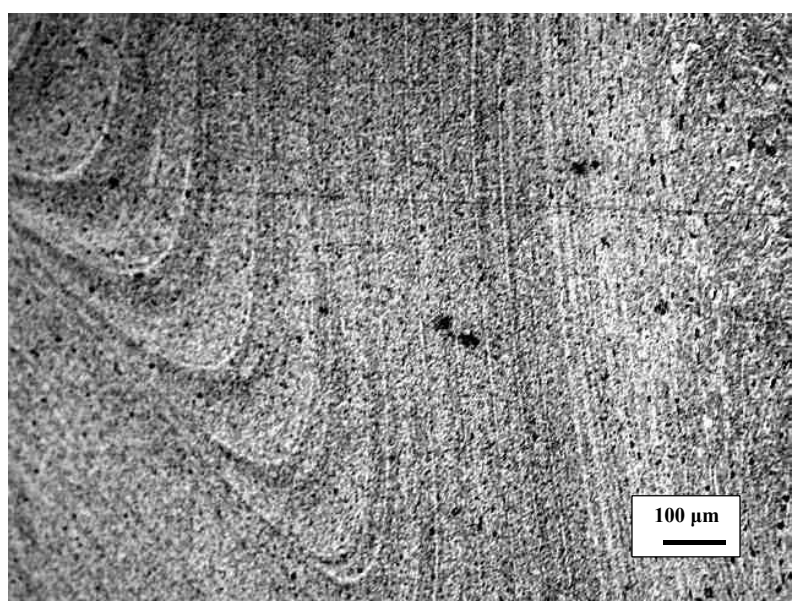

Fig. 4. Zone of the native alloy and the weld's nugget

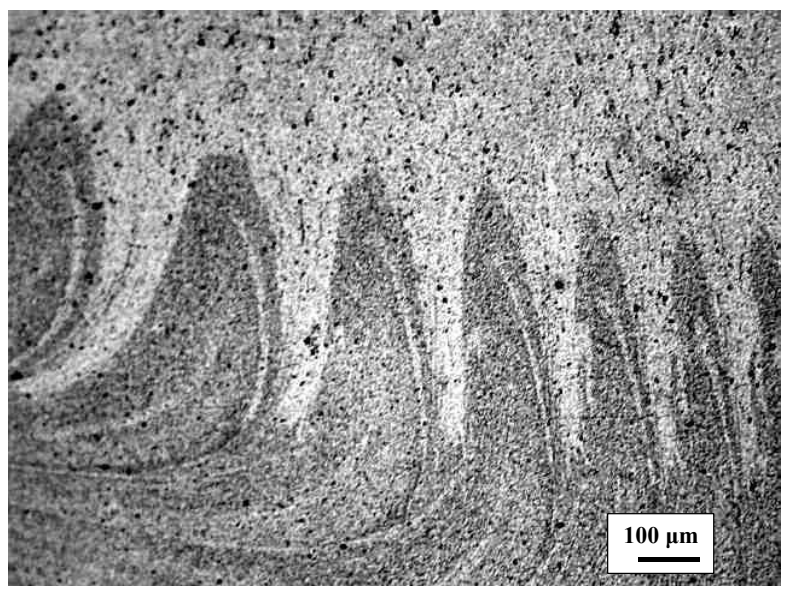

Fig. 5. The passing zone of the weld's nugget to the TMAZ

\subsection{Slow-strain rate testing (SSRT)}

Stress corrosion cracking (SCC) was examined via the slow-strain-rate-testing $\left(\dot{\varepsilon}=1,6 \times 10^{-6} \mathrm{~s}^{-1}\right)$ according to EN ISO 7539-7. The following parameters were measured: strain energy (the diagram surface under the stress-elongation curve) $-\mathrm{E}\left[\mathrm{MJ} / \mathrm{m}^{3}\right]$; time-to-failure $\mathrm{T}[\mathrm{h}]$, relative elongation of the specimen $-\mathrm{A}_{10}[\%]$; obtained max. load $-\mathrm{F}[\mathrm{N}]$; max. tensile stress $-\mathrm{R}$ $[\mathrm{MPa}]$ and narrowing $-\mathrm{Z}[\%]$. The tests were carried out on cylindrical notch-free specimens with diameter $\mathrm{d}=5 \mathrm{~mm}$ and measured length of $\mathrm{L}_{0}=50 \mathrm{~mm}$. Before testing, the specimens were deoiled. The fractures were analysed by electron scanning microscope of Philips XL 30 type.

\section{Results of experimental research}

\subsection{Tensile properties}

Table 3 presents results of mechanical properties test of the 5083 and 5059 (native material) and welded joints using the FSW and MIG method, carried out in flat samples (according to EN 895:1995) .

The strength properties of the tested aluminium alloys welded by friction stir welding are higher $\left(\mathrm{UTS}_{\text {weld }} / \mathrm{UTS}_{\text {native material }}=0.92\right)$ than those of the joints welded using popular MIG method. Metallographic and fractographic examinations were performed using an optical microscope and scanning electron microscope (SEM). The characteristic fractures of the welded joints made of Al-Mg alloys, being of mixed character, are shown in Fig. 6 and 7.

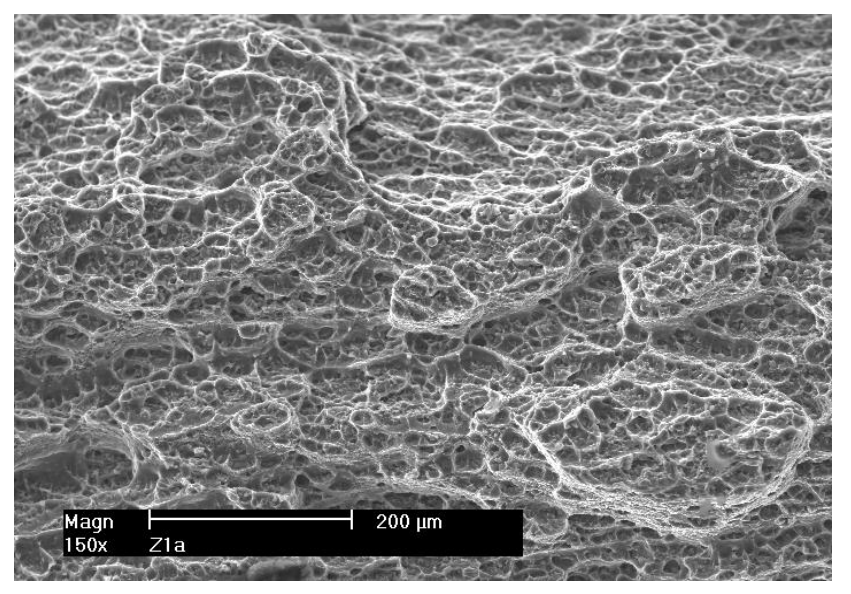

Fig. 6. The mixed fracture. Areas of ductile character on the fracture tips, some visible fragile fractions of the grain in the background. AW 5083 alloy welded by FSW method. 


\subsection{Results of SSRT}

The test results of the tested aluminum alloys and their welded joints (MIG and FSW), obtained in the slowstrain rate testing (SSRT), are presented in Table 4. Susceptibility to SCC is defined as the average percentage decrease in the values measured during the testing of parameters obtained in a corrosive environment, in compared with the values obtained in the air. The stress corrosion susceptibility was determined according to the formula (1):

$$
\mathrm{Kx}=\left(1-\frac{X S C C}{\text { Xair }}\right) \times 100 \%
$$

where:

- $\mathrm{Kx}$ - susceptibility to corrosion [\%],

- $X$ - value of the measured parameter during tests in a sea water equivalent $\left(\mathrm{X}_{\mathrm{SCC}}\right)$ or in air $\left(\mathrm{X}_{\text {air }}\right)$.

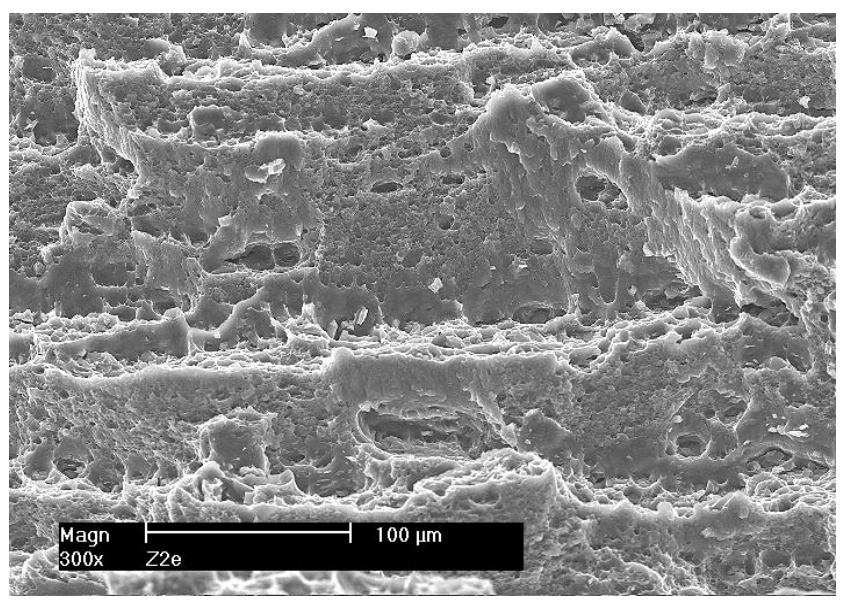

Fig. 7. The cleavage fracture with ductile areas. The welding line. AW 5059 material welded by FSW method.

Table 3. Mechanical properties of tested Al alloys and welded joints by MIG and FSW (average value from three specimens).

\begin{tabular}{|l|l|l|l|}
\hline Material & $\begin{array}{l}\text { UTS } \\
{[\text { MPa }]}\end{array}$ & $\begin{array}{l}\text { YS } \\
{[\text { MPa }]}\end{array}$ & $\begin{array}{l}\text { EL. } \\
{[\%]}\end{array}$ \\
\hline $5083 / /$ native alloy & 346,0 & 270,0 & 19.7 \\
\hline $5083 / / \mathrm{FSW}$ & 322.2 & 238.3 & 10.4 \\
\hline $5083 / / \mathrm{MIG}$ & 282,0 & 206,0 & 15.1 \\
\hline
\end{tabular}

\begin{tabular}{|l|l|l|l|}
\hline $5059 / /$ native alloy & 40,01 & 280,0 & 16.2 \\
\hline $5059 / / \mathrm{FSW}$ & 367.3 & 278.4 & 12.7 \\
\hline $5959 / / \mathrm{MIG}$ & 296.0 & 192.7 & 10.6 \\
\hline
\end{tabular}

\section{Discussion on the results of experimental research}

The analysis of the obtained test results shows that the AW 5083 alloy and the FSW welded joint are resistant to stress corrosion in sea water. The values of individual parameters measured in air and artificial sea water for the alloy welded using the FSW method do not differ (Table 4). SSRT in artificial seawater showed that the FSW joint made of 5059 alloy has better strength properties compared to the 5083 alloy welded by FSW. The stress corrosion resistance of both alloys is comparable.

Table 4. Corrosion susceptibility of welded Al alloys

\begin{tabular}{|l|l|l|l|l|l|}
\hline $\begin{array}{l}\text { Alloy//Welding } \\
\text { method }\end{array}$ & $\begin{array}{l}\mathbf{K}_{\mathbf{R}} \\
{[\%]}\end{array}$ & $\begin{array}{l}\mathbf{K}_{\mathbf{E}} \\
{[\%]}\end{array}$ & $\begin{array}{l}\mathbf{K}_{\mathbf{T}} \\
{[\boldsymbol{\%}]}\end{array}$ & $\begin{array}{l}\mathbf{K}_{\mathbf{A}} \\
{[\%]}\end{array}$ & $\begin{array}{l}\mathbf{K}_{\mathbf{Z}} \\
{[\boldsymbol{\%}]}\end{array}$ \\
\hline 5083/native material & 0.23 & 2.5 & 3.3 & 0.4 & 0.43 \\
\hline 5083/MIG & 2.23 & 4.6 & 0.4 & 0.7 & 0 \\
\hline 5083/FSW & 0.55 & 0 & 0.6 & 0 & 0 \\
\hline 5059/native material & 0.43 & 13.0 & 6.6 & 11.55 & 0 \\
\hline 5059/FSW & 1.33 & 3.2 & 1.38 & 1.5 & 2.0 \\
\hline 5959/MIG & 1.5 & 4.75 & 3.3 & 2.66 & 1.0 \\
\hline
\end{tabular}

$\mathrm{K}_{\mathrm{R}}$ - average $\%$ of maximum load decrease at the instant of specimen failure,

$\mathrm{K}_{\mathrm{E}}$ - average $\%$ of strain energy decrease,

$\mathrm{K}_{\mathrm{T}}$ - average $\%$ of elongation decrease at the instant of specimen failure,

$\mathrm{K}_{\mathrm{Z}}-$ average $\%$ of narrowing width decrease.

The FSW welded joints of both 5083 and 5059 alloys show better resistance to stress corrosion compared to 
MIG method. Elongation of samples made of 5059 alloy joints welded using FSW method, stretched in an aqueous $\mathrm{NaCl}$ solution, decreased by only $1.5 \%$ compared to the samples tested in air (Tab. 4). Decrease in the elongation value for MIG welded joints was $2.66 \%$. Likewise, AW 5083 - FSW welded joints have a good stress corrosion resistance, better than those made by MIG welding methods. In SSRT tests, an important parameter when analyzing the results is exposure time (time to failure). Fig. 8 shows the average times to failure for welded joints of AW 5059 alloy obtained in the stress corrosion susceptibility test. Table 5 shows the average times to failure of joints of 5059 alloy obtained during the SSRT test. The analysis of the results shows that the optimal welding method for the Al-Mg alloys, is FSW welding, where the time to failure is closest to the exposure time of the native alloy. Fig. 9 shows the elongation of aluminum alloys joints welded using the FSW method obtained in SSRT tests in air (air) and in aqueous $\mathrm{NaCl}$ solution $(\mathrm{NaCl})$.

During the SSRT tests, welded joints by FSW cracked between crystals, shearing along the welding line, between the native material and the welded joint (Fig. 10). Specimens made from welded joints by MIG cracked along the joint with a ductile fracture (Fig. 11). Fig. $12-14$ shows the examples of characteristic fractions of the notched specimens $(\mathrm{K})$ after the SSRT tests.

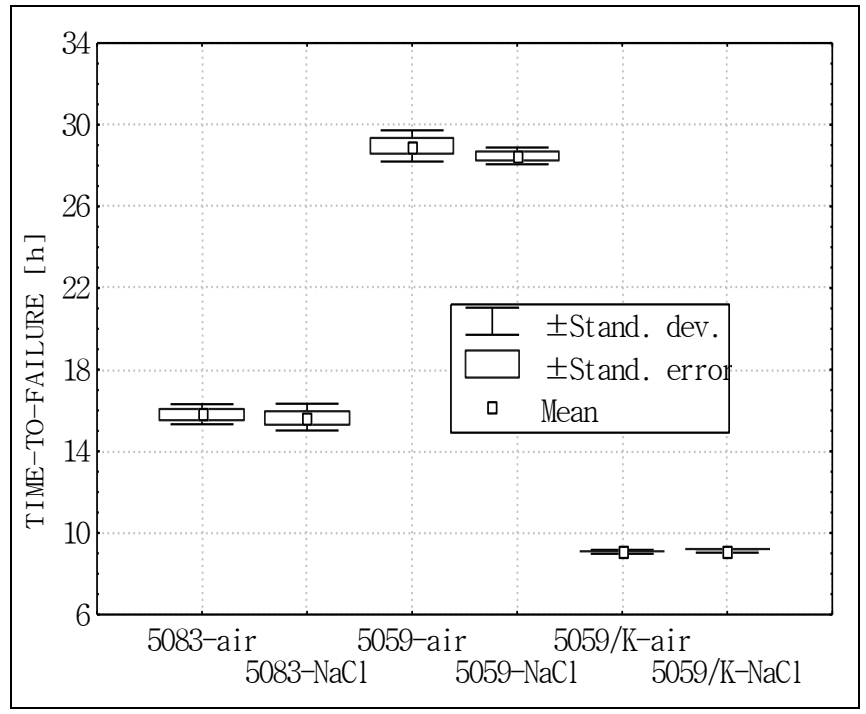

Fig. 8. Time-to-failure of notch-free specimens and notched specimens $(\mathrm{k})$ obtained in SSRT test for Al-Mg alloys FSWwelded. Tests carried out in the air (marked - air) and $\mathrm{NaCl}$ solution (marked $-\mathrm{NaCl}$ )

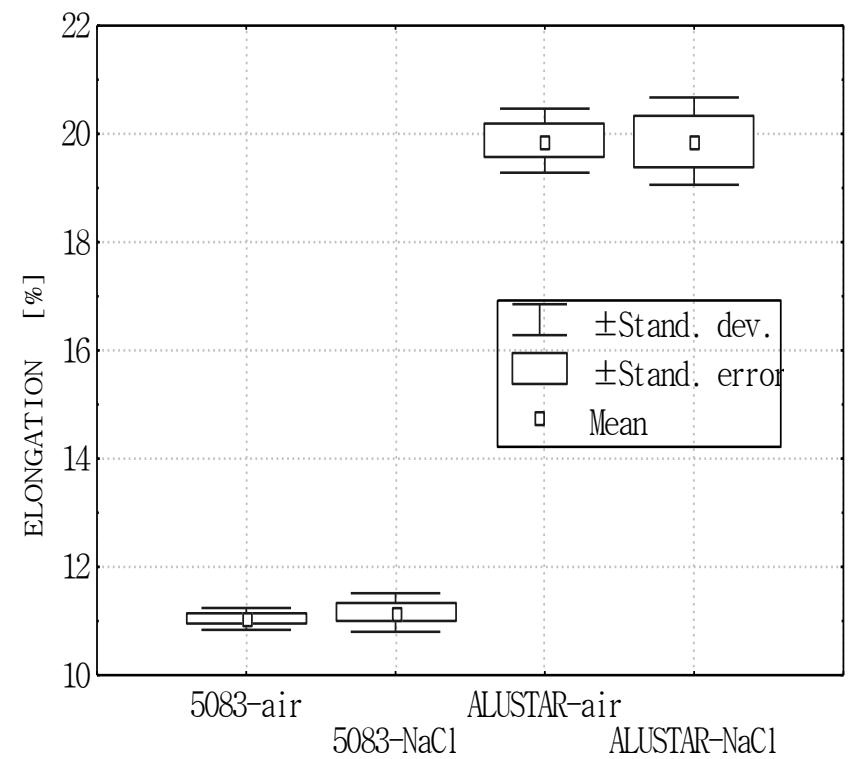

Fig. 9. Elongation of Al alloys FSW-welded method obtained in the SSRT tests in the air (air) and artificial sea water $(\mathrm{NaCl})$.

Table 5. Time-to-failure of 5059 alloy and welded joints (SSRT tests)

\begin{tabular}{|c|c|c|}
\hline Alloy & \multicolumn{2}{|c|}{ time-to-failure [h] } \\
\hline & Air & $\mathrm{NaCl}$ \\
\hline 5059 & 33.0 & 30.8 \\
\hline $5059 / / \mathrm{FSW}$ & 28.9 & 28.5 \\
\hline $5059 / / \mathrm{MIG}$ & 24.0 & 23.2 \\
\hline
\end{tabular}

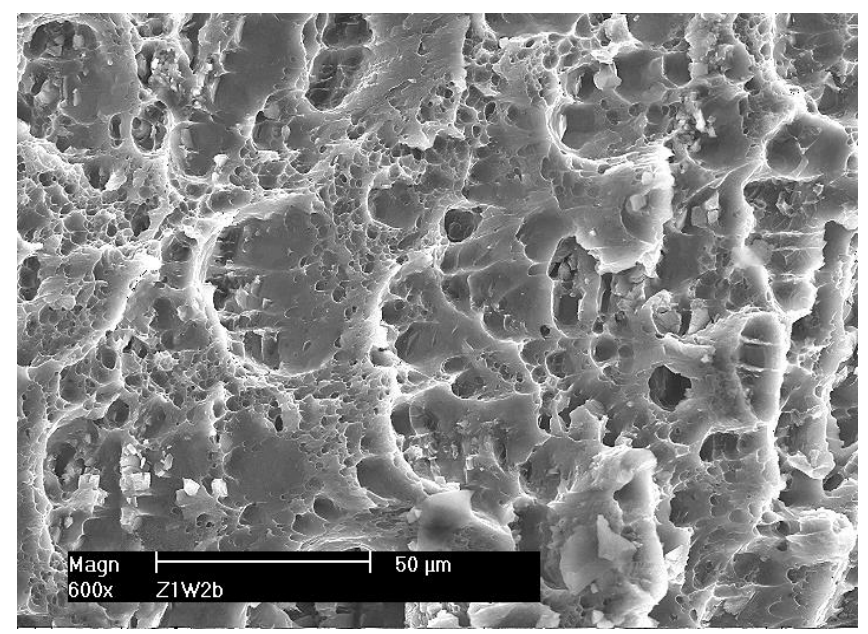

Fig. 10. Fracture of AW 5083 alloy welded by FSW, after being exposed in $\mathrm{NaCl}$. The fracture area with band of dimples, being parallel toward the direction of cutting. 


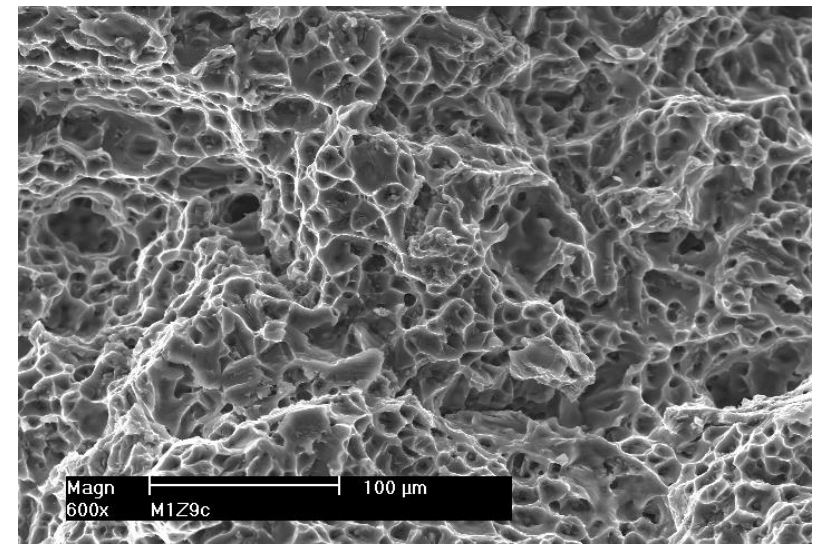

Fig. 11. Fracture of 5083 alloy MIG- welded. The fracture of the notched specimens made of 5059 alloy

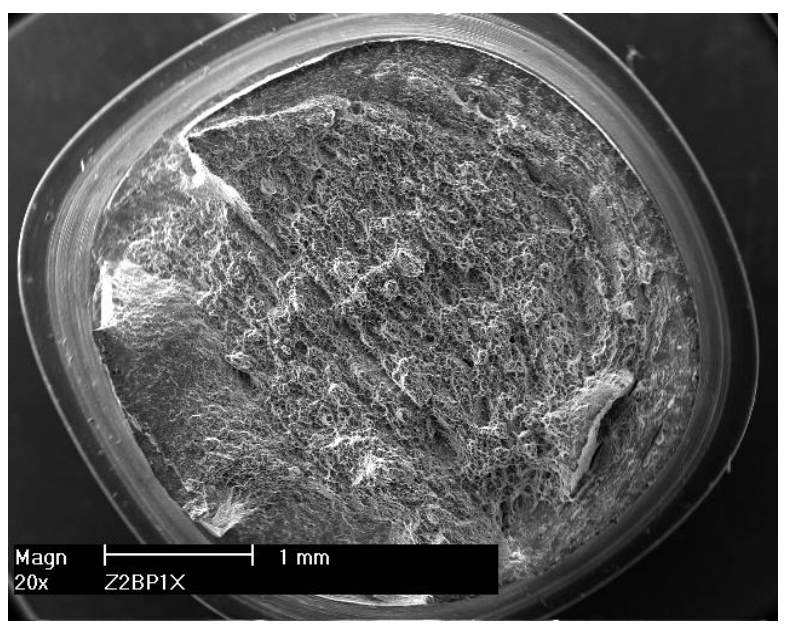

Fig.12. The fracture of the notched specimens made of 5059 alloy FSW- welded. In the middle plastically strained area of the weld nugget is visible.

\section{Conclusions}

The analysis of the obtained research results allows for drawing conclusions:

1. Welding Al-Mg alloys using the FSW method allows for obtaining joints with higher strength properties $\left(\mathrm{UTS}_{\text {weld }} / \mathrm{UTS}_{\text {native material }}=0.92\right)$ compared to MIG welded joints.

2. AW 5083 alloy joints welded using the FSW method show good resistance to stress corrosion cracking determined in the slow strain rate test (SSRT).

3. During the SSRT tests, joints welded by FSW cracked between crystals, shearing along the welding line, between the native material and the welded joint. Specimens made from welded joints by MIG cracked along the joint with a ductile fracture.

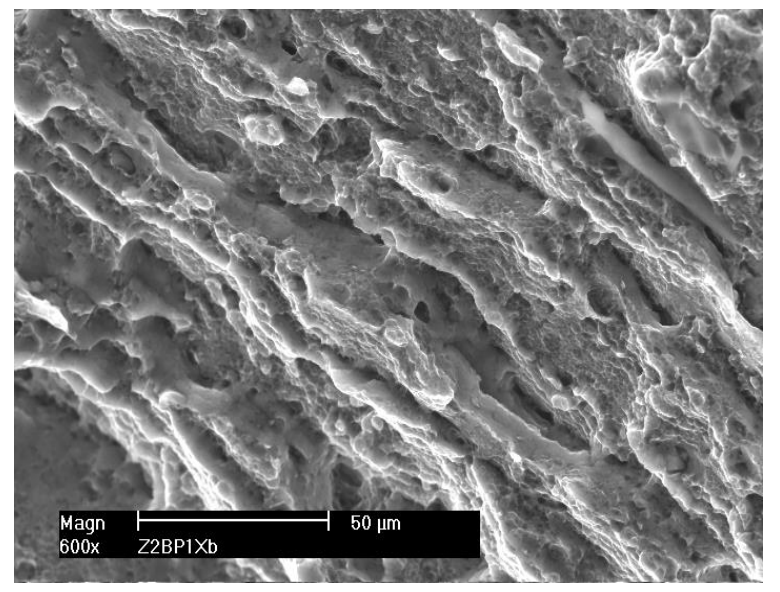

Fig. 13. Fragment of the fracture seen in Fig. 12. The area of the weld nugget. Mixed fracture.

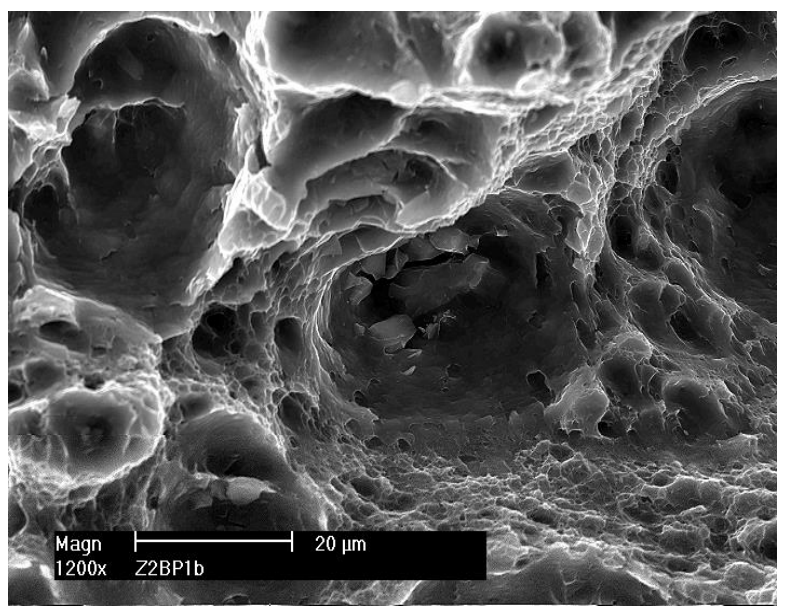

Fig. 14. Fragment of the fracture from Fig. 12. The ductile fracture with visible dimples and cracked inter-metallic phases.

4. Tests have shown that the AW-5059 alloy welded using the FSW method has good resistance to stress corrosion cracking with better strength properties compared to the 5083 alloy welded using the FSW method.

5. 5059 alloy welded using the FSW method are characterized by good resistance to stress corrosion cracking - better than joints made by MIG welding.

\section{References}

[1] Thomas W.M., Friction stir welding. GB patent 9125978, 6.12.1991, International patent application PCT/GB92/02203.

[2] Czechowski M., Pietras A., Zadroda L., The properties of aluminium alloys $5 \mathrm{xxx}$ series welded by new technology Friction Stir Welding, Inżynieria Materiałowa, Vol. 137, No. 6, 2003, pp. 264-266. 
[3] Eriksson L.G., Larsson R., Friction Stir Welding - progress in R\&D and new applications, Svetsaren, Vol. 57 No. 2, 2002, pp. 11-13.

[4] Eriksson L.G., Friction stir welding, Svetsaren, Vol. 56, No. 2-3, 2001, pp. 3-6.

[5] Davis J. R.: Corrosion of Aluminium and Aluminium Alloys, ASM International, Materials Park, OH, 1999.

[6] Lumsden J.B., Mahoney M.W., Rhodes C.G. Pollock G.A., Corrosion Behavior of FrictionStir-Welded AA 7050-T7651, Corrosion, Vol. 59, No. 3, 2003, pp. 212-219.

[7] Squillace A., Fenzo A., Giorleo G., Bellucci F., A comparison between FSW and TIG welding techniques: modifications of microstructure and corrosion resistance in AA 2024-T3 butt joints. Materials Processing Technology, Vol. 152, 2004, pp. 97-105.

[8] Meng, C., Zhang, D., Cui, H., Zhuang, L., \& Zhang, J. Mechanical properties, intergranular corrosion behavior and microstructure of $\mathrm{Zn}$ modified Al-Mg alloys. Journal of Alloys and Compounds, 2014, Vol. 617, p 925-932.

[9] Zeng X. H., Wang D., Ni D. R., Wang K. S. \& Ma Z.Y., Material flow and void defect formation in friction stir welding of aluminium alloys, Science and Technology of Welding and Joining, Vol. 23, 2018, pp. 677-686.

\section{Creative Commons Attribution License 4.0 (Attribution 4.0 International, CC BY 4.0)}

This article is published under the terms of the Creative Commons Attribution License 4.0

https://creativecommons.org/licenses/by/4.0/deed.en_US 